\title{
Research on Internationalization of Wuhan Enterprises and Language Service Needs \\ Dan $\mathrm{ZHOU}^{1, \text { a }}$, Yonglin $\mathrm{CHEN}^{2, \mathrm{~b}}$ \\ ${ }^{1}$ School of Foreign Languages, Wuhan Textile University, Wuhan, 430200, China \\ ${ }^{2}$ Hubei Preschool Teachers College, Wuhan, 436032, China \\ aemail: Zhoudan@wtu.edu.cn, bemail: chenyonglin693@163.com
}

Keywords: Wuhan Local Enterprises; Business Management; Internationalization; Language Services; International Publicity Translation

\begin{abstract}
Cross-cultural conflicts can be resolved by the language during the process of internationalization, which is conducive to new enterprises to adapt new business environment and promotes the localization of enterprises. In this paper, by analyzing the inner connection between language services and business internalization, it discusses how to advance the internationalization of Wuhan local enterprises from various aspects such as the background information on the company, the construction of multilingual website, the staff training of language services and the enterprise product promotion.
\end{abstract}

\section{Introduction}

To go out, it urgently needs Chinese standards for Chinese companies, capital and technologies. However, the related language services lag. [1] Compared with the standard English rate of more than $40 \%$ in Japan, South Korea and Germany, the rate in China is still less than 5\%. In the internalization process of Chinese standards, it calls for large quantities of translation of Chinese standards and active participation in international standardization activities whose cores are language service problems. [2] To carry out "Going out" strategy of Chinese standards, this paper raises that it needs at least four steps: first, strengthening basic language education and standardization of knowledge education in both Chinese and English; second, developing professional talents of international standards and building bilingual parallel corpus and intelligent translation platform; third, translating the Chinese standards, participating in the internationalization activities and setting up Chinese standard overseas agencies. Fourth, adopting Chinese standards in international projects and transforming them into international standards. [3]

\section{Current Situation of Language Service Industry}

As a new emerging industry, language service industry includes translation and localization service, tool development of language technology, language teaching and training, related advisory services and so on, which has been far beyond the traditional translation industry and becomes an important part of global industrial chain. Chinese language service industry appears in the 1980s along with our country's reform and opening up policy and takes initial shape in 1990s with the development of information technology. [4] After entering the $21^{\text {st }}$ century, the language service market is greatly promoted by globalization and the development of service outsourcing industry. Chinese language service industry ushers in rapid development. [5]

\section{Present Situation of Wuhan local Enterprises}

\section{A. Non-standard translation of company profile}

Company profile helps the company set up the corporate image by foreign publicity. 83\% of enterprises in Wuhan have their English company profile by translating the Chinese version which 
can not provide referable information for the foreign side. [6] Some profile covers the leaders' inscription for the company, while foreign customers believe that consumer response is the best criteria which emphasize public opinions.

\section{B. Insufficient website construction of multilingual foreign trade}

Along with the accelerating internationalization, enterprises must build multilingual website to export their products. According to statistics, more than $80 \%$ of users are more willing to buy products and services recommended in their native languages. 99\% of foreign buyers search on the Internet in their mother tongue. [7] It is one of the effective marketing strategies of differentiation by adopting multilingual marketing so that foreign consumers can browse the company's products in their mother tongue. So far, $80 \%$ of Wuhan enterprises have the problem of insufficient and low-level website construction of foreign trade which largely restricts the effectiveness of the overseas product promotion.

\section{Wrong usage of standard language}

Staff of export enterprises inevitably need to contact with foreign customers. Therefore, the language services offered may not reach the designated position due to cultural differences between different countries. For example, on January 7, 2009, a foreign client came to a logistics company in Wuhan for delivery. When the customer wanted to tie up the goods with adhesive tape there, the conflict occurred due to improper communication between the staff and the client accompanied by impolite expressions which caused strong dissatisfaction to the customer. Finally, the customer made a complaint to call center of the group company and went to other logistics company.

\section{Non-standard translation of export products}

Some instructions and symbols, such as nameplate, warnings, instructions, and graphical symbols and so on, are one of the important content of product safety standards. However, in the production test of export goods, non-standard, incomplete or even wrong cases are common occurrence. Foreign notification cases also appear frequently. All seriously affect the overall quality and image of export products. For instance, some export company in "Chinese medicine city" Bozhou translated “妇炎宝” into “Complexion-nourishing Pills for Ladies”. In fact, it is a kind of health care medicine which is used to treat some female symptoms such as endocrine disorder. It is more accurate to be translated as "Gyne-cure (the medicine for the treatment of gynecological diseases).

\section{Survey Result and Countermeasures}

\section{A. Improving the translation of company profile}

From the stylistic point of view, company profile is one of the types of specification and belongs to the practical writing of foreign trade; for the discourse type, it belongs to "information, encouraging discourse" and plays the publicity function. Wuhan local enterprises should put their emphasis on the customer feedback in the English introduction and apply languages as a customer. First, words are encouraging. For example, “拥有雄厚的技术力量” can be translated into "Boasting tremendous technological strength"; Second, use some stylization expressions. For instance,“合资企业”can be translated into” joint venture” which reflects the nature of the company; Third, use slogans frequently. The translation can borrow some common expressions in the company profile “质量第一, 信誉第一, 服务至上, 平等互利” can be translated into “Quality Primacy, High Reputation, Service Supremacy, Equality and Mutual Benefit”. 
B. Promoting the multilingual website construction of Wuhan enterprises

As the basic step of communication, the English website serves as vanguard for brands of Wuhan enterprises to expand overseas. Therefore, Wuhan local enterprises must increase investment in translation and Web Design in the website construction to achieve Website localization, including localization of the structure and localization of the content. Besides, they should also constantly optimize the website.

\section{Strengthen the language training of employees of Wuhan enterprises}

Local enterprises should be fully aware of the importance of communication between service personnel and customers in the process of internationalization. First of all, pay attention to the appropriateness of appellation and greet customers by Miss, Mr. and Mrs. Service personnel should precisely introduce the product in customers' mother tongue with their own knowledge. In this aspect, it requires enterprises to employ native speakers for the language training and translation skills of employees. Only then can they serve customers better.

\section{Enhancing the product promotion}

Product name is the core of the product image. Taking Wuhan Cherry Automobile co., LTD for example, four export types of the company are “风云”, “旗云”, “东方之子” and “QQ”. “QQ” is translated into Cherry. “旗云” is translated into COWIN. Even “东方之子” is translated in Chinese Pinyin. All the translations are far inferior to that of AUDI, BENZ, BMW and other foreign automobile brands. In product promotion, Cherry Automobile co., LTD should fully consider the translation of product name based on following translation principles:

(1) Retaining the pronunciation of the original brand;

(2) Reflecting the information of the product with its features;

(3) Using commendatory and neutral words as unique brand names which can impress customers and give them good associations.

\section{Conclusion}

Wuhan is located in central region of China with abundant natural resources and human resources. Local enterprises should make full use of these advantages and strive to be forerunners of "Going out" and make due contribution to economic development of Wuhan. Just like Felix Green, an English man, says: "We are not Chinese", foreigners are different from Chinese in language, culture, ideology, national psychology, historical background, habits and customs. Therefore, the international publicity translation of local enterprises should meet the demands of their practical development and abroad development. Enterprises should be adept at the use of modern means and international common rules to increase the attraction and affinity of foreign publicity. They can also use language skills to increase labor income and employment of Wuhan enterprises.

\section{Acknowledgement}

In this paper, the research was sponsored by Foundation of Science and Technology Department of Hubei Province soft science research project (湖北省技术创新专项软科学项目资助) (Project No. 2016ADC078) and Foundation of Hubei Educational Committee (Project No. 2016GB036).

\section{References}

[1] Basic Concepts and Models for Interpreter and Translator Training. Gile Daniel. Journal of Women s Health . 1995 
[2] Political capabilities, policy risk, and international investment strategy: evidence from the global electric power generation industry [J]. Guy L. F. Holburn, Bennet A. Zelner. Strat. Mgmt. J.2010 (12)

[3] A TQM Approach to Translator Training [J]. Moustafa Gabr. The Interpreter and Translator Trainer . 2007 (1)

[4] A Report on C-E Translation of Communications Documentation from the Perspective of Skopos Theory [D]. XUE Hong .XI’ AN INTERNATIONAL STUDIES UNIVERSITY 2016

[5] Introducing Translation Studies: Theories and Applications. Munday, Jeremy. . 2001

[6] A Cognitive Apprenticeship-based Model for Acquiring Localization Skills [D]. ZHAO Wenbin. XI’ AN INTERNATIONAL STUDIES UNIVERSITY, 2014

[7] Text Analysis in Translation: Theory, Methodology, and Didactic Application of a Model for Translation-Oriented Text Analysis. Nord,Christiane. . 1991 